\title{
Primary Central Nervous System ALK-Positive Anaplastic Large Cell Lymphoma: Clinicopathologic and Prognostic Features
}

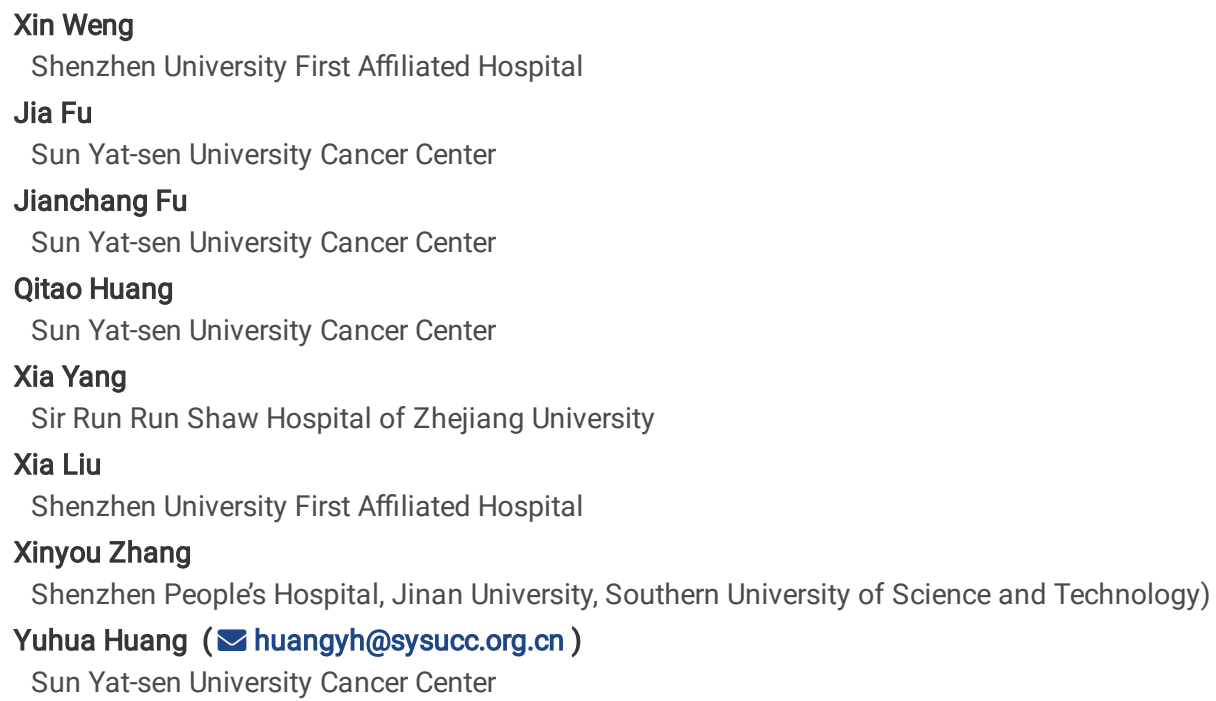

\section{Research Article}

Keywords: Primary, Central Nervous System, ALK-positive Anaplastic Large Cell Lymphoma, Clinicopathologic Features

Posted Date: February 25th, 2022

DOI: https://doi.org/10.21203/rs.3.rs-1383600/v1

License: (c) (i) This work is licensed under a Creative Commons Attribution 4.0 International License. Read Full License 


\section{Abstract \\ Background}

Primary CNS anaplastic lymphoma kinase-positive (ALK+) anaplastic large cell lymphoma (ALCL) is extremely rare and only few cases have been reported. Due to its rarity, the clinicopathologic features and the prognosis of primary CNS ALK + ALCL have not been well characterized.

\section{Methods}

We retrospectively analyzed the clinicopathologic and prognostic features of 3 cases of primary CNS ALK + ALCLs among 337 cases of primary CNS lymphomas during the past 14 years in our cancer center with review of an additional 20 cases from the literature.

\section{Results}

Primary CNS ALK + ALCL accounted for $0.9 \%$ (3/337) of all primary CNS lymphomas during the study period in our cancer center. The ages of patients ranged from 4 to 43 years, with a median age of 18 years. There was a predominance of males, with the male-to-female ratio of $6.7: 1$. Most (87\%, 20/23) of cases had intracerebral mass(es), and among these cases, $25 \%(5 / 20)$ of cases were accompanied by involvement of spinal cord and (or) leptomeninges; rare cases $(3 / 23,13 \%)$ were confined to the spinal cord and (or) leptomeninges. A solitary mass and multiple tumors were present in $56.5 \%(13 / 23)$ and $43.5 \%(10 / 23)$ of cases, respectively. Of the 22 patients with survival data, $31.8 \%(7 / 22)$ of patients died of the disease during the follow-up period (median follow-up, 24 months; range, 0.5-87 months). The 2-year overall survival (OS) of patients with primary CNS ALK + ALCL was $69 \%$. Patients under 18-years old had worse 2-year overall survival, but the difference did not reach statistical significance $(p=0.115)$. No statistical significance was found between patients with solitary mass and multiple tumors $(p=0.940)$.

\section{Conclusions}

Primary CNS ALK + ALCL is an extremely rare disease and tends to occur in young adults with a male preponderance. Patients with this disease have relatively favorable outcome than other types of primary CNS lymphomas. Accurate diagnosis, as well as timely and optimal treatment for patients with this disease is important.

\section{Background}

Primary central nervous system lymphoma (PCNSL) is a relatively rare disease accounting for $2.4-3 \%$ of all brain tumors(1). The most majority histological type of PCNSL is diffuse large B-cell lymphoma (DLBCL) and patients with CNS DLBCL have remarkably worse outcome than do patients with systemic DLBCL(2). Other types of lymphoma have just occasionally been seen in CNS.

Primary CNS anaplastic large cell lymphomas (ALCLs) are rare, most of which are ALK+, while only a minority of cases are ALK-1 negative(3). Up to date only few cases of primary CNS ALK + ALCL have been reported, mainly as case reports rather than as study series(4-20). Because of its rarity, the clinicopathologic and prognostic features of primary CNS ALK + ALCL have not been well illuminated. In an attempt to expand the current knowledge of the occurrence, clinicopathologic characteristics and prognosis of this rare tumor, we retrospectively analyzed 3 cases of primary $C N S$ ALK + ALCL among 337 cases of primary CNS lymphomas during the past 14 years in our cancer center with review of an additional 20 cases from the literature.

\section{Materials And Methods}

\section{Case Selection}

All cases of PCNSLs diagnosed in the Department of Pathology, Sun Yat-sen University Cancer Center, Guangzhou, China, were retrospectively analyzed during the period from January, 2007 to December, 2020. Primary CNS ALK+ ALCL cases were collected. The inclusion criterions of this retrospective study were as followings: (1) patient was without a history of lymphoma; (2) CNS lesion was as the initial presentation without extra CNS or lymph node manifestations at presentation; (3) lymphoma of the dura, intravascular lymphoma, lymphomas with evidence of systemic disease or secondary lymphomas, and all immunodeficiency-associated lymphomas were excluded. The clinical data collected for analysis included age, location, clinical presentation, treatment regiments, and survival data. All patients provided written informed consent for the collection and publication of their medical information during the first visit to the hospital.

We also performed an extensive literature search for the reported cases of primary CNS ALK+ ALCL in PubMed (www.ncbi.nlm.nih.gov/pubmed/) using different combinations of key words in the title/abstract field, including "primary," "CNS," "central nervous system," "ALK", "ALK1", "ALCL," and "anaplastic large cell lymphoma". Cases in the English literature were carefully reviewed to extract essential clinicopathologic data and to combine the cases that were repeatedly studied in different papers. A total of 20 cases of primary CNS ALK+ ALCL were retrieved from the literature and were included in our review. 
The specimens of these 3 cases of primary CNS ALK+ ALCL cases were formalin fixed and paraffin embedded (FFPE) and then sectioned at 4.0 mm thickness. The sections were stained using hematoxylin and eosin staining or were used for immunohistochemical examination. The immunohistochemical stains were performed on a Leica Autostainer (BOND-MAX, M495644) with Bond Polymer Refine Detection Kit (Leica Biosystems Newcastle Ltd, Catalog No.: DS9800). Appropriate negative and positive controls were performed with satisfactory staining. The pretreatment methods, primary antibodies, and their working dilutions are listed in Table 5.

The EBV Probe In Situ Hybridization Kit (ISH- 6021, Zhongshan Golden Bridge Biotechnology Co. Ltd, Beijing, China) was used to detect EBV-encoded small RNAs (EBERs) according to the manufacture's protocol. The main protocols were published in our previous paper(21). The positive signals were a brownish-yellow color and localization in the nuclei.

\section{Molecular Assays for Gene Rearrangements}

Genomic DNA was extracted from FFPE tissue using the QIAamp DNA FFPE Tissue Kit (Qiagen, Hilden, Germany). A commercial BIOMED-2 multiplex PCR system (Invivoscribe Technologies, San Diego, CA) was used to detect the gene rearrangements of T cell receptor (TCR) and immunoglobulin (Ig) in Case \#1 and \#2 according to previously published methods(22). Gene scanning was performed on ABI 3500XI Genetic Analyzer using GeneMapper Software (version 4.1; Life Technologies Corporation, Carlsbad, CA, USA) with appropriate positive and negative controls. Interpretation of clonal peak was carried out as per the EuroClonality guideline and the manufacturer's protocol.

\section{Statistical Analysis}

Among these 23 cases of primary CNS ALK+ ALCL, survival data of 22 cases were available for analyses, including 3 cases from present study and 19 cases in the literature. Survival was defined as years from first diagnosis of primary CNS ALK+ ALCL to death or last follow-up. Those alive at last followup were treated as censored. The Kaplan-Meier method was used to estimate overall distributions, and the log-rank test was used to compare survival distributions by patient groups. P-values $<0.05$ ( 2 sided) were considered to be statistically significant. The Life Table method was used to estimate overall distributions. SPSS software (version 26.0 for Mac; Statistical Product and Service Solutions; IBM, Armonk, NY) was used for analysis.

\section{Results}

\section{Occurrence and Patient's Clinical Characteristics}

Primary CNS ALK+ ALCL accounted for $0.9 \%$ (3/337) of all primary CNS lymphomas during the study period in our cancer center. The major clinical features of the 3 cases of primary CNS ALK+ ALCL are summarized in Table 1. All 3 patients were males and ranged from 12 to 27 years with a median age of 16 years at diagnosis. All patients were Chinese without a history of lymphoma. The average clinical course was 4 months (range, 2 to 6 months). All patients initially presented with headache and vomiting or dizziness. Patient $1 \#$ and $2 \#$ had a single lesion located in right frontal lobe (Fig.1) and right parieto-occipital lobe, respectively, whereas Patient $3 \#$ had multiple lesions mainly located in cerebellum.

\section{Pathology Findings}

\section{Histology}

Histopathologically, normal brain architectures were replaced by lymphoid cells (Fig. 2A). The tumors had a diffuse growth pattern largely effacing the brain tissues, and some neoplastic cells often clustered around blood vessels in all 3 cases (Fig. 2B). Cytologically, the lymphomas were composed predominantly of large sized cells with abundant cytoplasm and irregular nuclei in all cases. The nuclear chromatin was finely clumped or dispersed, with prominent nucleoli (Fig. 2C-2D). The mitotic figures were visible. All these 3 cases were of common type.

\section{Immunophenotype}

The results of immunohistochemistry and EBER in situ hybridization (ISH) are summarized in Table 2. All 3 cases showed that neoplastic cells were stained strongly for $\mathrm{CD} 30$ on the cell membrane and in the Golgi region (Fig. 3A). ALK-1 positivity was identified in all cases, with staining in both cytoplasm and nucleus (Fig. 3B). All cases were positive for MUM1(Fig. 3C) and the cytotoxic antigens (TIA1, granzyme B) (Fig. 3D). Two available cases were positive for EMA (Fig. 3E) and CD43, CD2, CD3Eand CD7 were partially positive in one available case, respectively. All cases were negative for B cell markers, including CD20 and CD79a. The Ki-67 proliferation fraction ranged from $60 \%$ to $80 \%$ (Fig. 3F). In situ hybridization for EBER was negative for all 3 cases.

\section{Gene Rearrangements}

PCR assays for TCR and IG gene rearrangements were performed on Case 1\# and Case 2\#. Both showed monoclonal T-cell receptor (TCRY) gene rearrangement, but without IG gene rearrangement.

\section{Treatment and Outcome}

All 3 patients underwent surgical resection and chemotherapy (treatment regimens for each case was listed in Table 1). In addition, Case 2\# and Case $3 \#$ received whole brain radiotherapy. All patients were successfully followed-up. The median follow-up interval was 52 months (range, 18 to 98 mo). All 
patients survived without diseases during the follow-up period, and of note, patient $3 \#$ survived for 98 months.

\section{Review of 23 Cases of Primary CNS ALK+ ALCL}

After an extensive search of the English literature, we found 20 cases of primary CNS ALK+ ALCL(4-20). Some cases were included in two articles with different study purposes, and the data from these cases were carefully extracted and combined. The brief clinicopathologic features of these cases and those from the present study are summarized in Table 3. The ages of patients ranged from 4 to 43 years, with a median age of 18 years. There was a predominance of males, with the male-to-female ratio of $6.7: 1$. Most $(87 \%, 20 / 23)$ of cases had intracerebral mass(es), and among these cases, $25 \%$ $(5 / 20)$ of cases were accompanied by involvement of spinal cord and (or) leptomeninges; rare cases (3/23,13\%) were confined to the spinal cord and (or) leptomeninges. A solitary mass and multiple tumors were present in $56.5 \%(13 / 23)$ and $43.5 \%(10 / 23)$ of cases, respectively. Of the 22 patients with survival data, $31.8 \%$ (7/22) of patients died of the disease during the follow-up period (median follow-up, 24 months; range, $0.5-87$ months). The 2-year overall survival (OS) of patients with primary CNS ALK+ ALCL was 69\% (Fig. 4A). Patients under 18-years old had worse 2-year overall survival, but the difference did not reach statistical significance $(p=0.115)$ (Fig. $4 \mathrm{~B})$. No statistical significance was found between patients with solitary mass and multiple tumors $(p=0.940)$

\section{Discussion}

$\mathrm{ALK}+\mathrm{ALCL}$ frequently involves both lymph nodes and extranodal sites. The most commonly involved extranodal sites include the skin, bone, soft tissue, lungs, and liver(23-26). Involvement of the CNS is rare(2). Of all cases of ALCL, $<1 \%$ are primary in CNS(27). Our results revealed that primary CNS ALK + ALCL only accounted for $0.9 \%$ (3/337) of all primary CNS lymphomas during the study period in our cancer center. After an extensive search of the English literature, only 20 cases of primary CNS ALK + ALCL were identified. Hence, these data once again support that primary CNS ALK + ALCL is extremely rare. Interestingly, primary CNS ALK + ALCL mostly affected male patients with a male to female ratio of 6.7:1. The ages of patients ranged from 4 to 43 years, with a median age of 18 years. Accordingly, it seems that primary CNS ALK + ALCL tends to occur in young adults with a male preponderance.

Due to its rarity, the clinicopathologic features and the prognosis of primary CNS ALK + ALCL have not been well characterized. Up to date, no known risk factors have been identified. Patients mainly initially presented with headache, dizziness, vomiting, seizures, or a combination of these. They are often initially thought to have an infection rather than a neoplasm, especially for the cases with multiple lesions. When combined with the cases previously reported in the literature, we found that most $(87 \%, 20 / 23)$ of cases had intracerebral mass(es), and among these cases, $25 \%(5 / 20)$ of cases were accompanied by involvement of spinal cord and (or) leptomeninges; rare cases $(3 / 23,13 \%)$ were confined to the spinal cord and (or) leptomeninges. $A$ single lesion was slightly more common than multiple lesions, which were observed in $56.5 \%$ and $43.5 \%$ of patients, respectively. Of note, the morphology and immunophenotype of primary CNS ALK + ALCL are similar to systemic ALCL. Most cases of this entity are of common type, but primary CNS ALK + $\mathrm{ALCL}$ of the lymphohistiocytic variant(27) and combined lymphohistiocytic and small-cell variants have also been reported(28).

The most majority of PCNSL is DLBCL and patients with CNS DLBCL have remarkably worse outcome than do patients with systemic DLBCL(2). Patients with systemic ALK + ALCL show favorable outcome. However, the outcome and the prognostic risk factors of primary CNS ALK + ALCL have not been well characterized. Only few cases have been reported, mainly as case reports rather than as study series. Recommendations regarding therapies are unavailable due to the small numbers of disparately treated cases. Most reports do describe therapy segments and outcomes, but consensus statements about the best therapeutic intervention are not available. Our results showed that the 2-year overall survival (OS) of patients with primary CNS ALK + ALCL was $69 \%$. Of note, all 3 patients from our cancer center survived during the follow-up period with median follow-up interval of 52 months, and patient $2 \#$ survived for 98 months. Hence, patients with this disease have relatively favorable outcome. Accurate diagnosis, as well as timely and optimal treatment for patients with this disease is important. Interestingly, patients under 18-years old showed a trend toward inferior overall survival, which had not been reported previously. No statistical significance was found between patients' outcome and gender, number of lesions.

\section{Conclusions}

Primary CNS ALK + ALCL is an extremely rare disease, which only accounted for $0.9 \%(3 / 337)$ of all primary CNS lymphomas during the past 14 years in our cancer center. It tends to occur in young adults with a male preponderance. Patients with this disease have relatively favorable outcome than other types of primary CNS lymphomas. Accurate diagnosis, as well as timely and optimal treatment for patients with this disease is important.

\section{Declarations}

\section{Compliance with Ethical Standards:}

\section{Funding}

There is no financial support for this study.

\section{Disclosure of potential conflicts of interest}

The authors declare that they have no conflict of interest. 


\section{Ethical approval}

This article does not contain any studies with human participants or animals performed by any of the authors.

\section{Informed consent}

All patients provided written informed consent for the collection and publication of their medical information during the first visit to the hospital.

\section{Authors' contributions}

Xin Weng designed the study and wrote the manuscript. Jia Fu and Jianchang Fu contributed to the clinical and follow-up information collection, as well as data analysis. Qitao Huang, Xia Yang and Xia Liu performed immunohistochemical staining and in situ hybridization (ISH). Xinyou Zhang provided supervision. Yuhua Huang conceived the project and provided leadership.

\section{References}

1. Schlegel U. Primary CNS lymphoma. Ther Adv Neurol Disord 2009; 2, 93-104.

2. Swerdlow SH, Campo E, Harris NL, et al. WHO Classification of Tumours of Haematopoietic and Lymphoid Tissues. Fourth Edition; 2017 ; p300-413.

3. Lannon M, Lu JQ, Chum M, Wang BH. ALK-negative CNS anaplastic large cell lymphoma: case report and review of literature. Br J Neurosurg 2020, $1-6$.

4. Liu Q, Chen X, Li G, Ye Y, Liu W, Zhao S, Zhang W. Primary central nervous system ALK-positive anaplastic large cell lymphoma with CD56 abnormally expression in a Chinese child: Challenge in diagnostic practice. Int J Immunopathol Pharmacol 2020; 34, 2058738420941756.

5. George DH, Scheithauer BW, Aker FV, Kurtin PJ, Burger PC, Cameselle-Teijeiro J, McLendon RE, Parisi JE, Paulus W, Roggendorf W, Sotelo C. Primary anaplastic large cell lymphoma of the central nervous system: prognostic effect of ALK-1 expression. Am J Surg Pathol 2003; 27, 487-493.

6. Abdulkader I, Cameselle-Teijeiro J, Fraga M, Rodriguez-Núnez A, Allut AG, Forteza J. Primary anaplastic large cell lymphoma of the central nervous system. Hum Pathol 1999; 30, 978-981.

7. Buxton N, Punt J, Hewitt M. Primary Ki-1-positive T-cell lymphoma of the brain in a child. Pediatr Neurosurg 1998; 29, $250-252$.

8. Carmichael MG. Central nervous system anaplastic large cell lymphoma in an adult: successful treatment with a combination of radiation and chemotherapy. Mil Med 2007; 172, 673-675.

9. Cooper PB, Auerbach A, Aguilera NS, Adair C, Moores L, Geyer D, Rushing EJ. Rare primary CNS anaplastic large cell lymphoma in an immunocompetent adult: a clinical-pathologic case report and review case of the literature. Clin Neuropathol 2006; 25, $232-236$.

10. Dong X, Li J, Huo N, Wang Y, Wu Z, Lin X, Zhao H. Primary central nervous system ALK-positive anaplastic large cell lymphoma in an adult: A rare case report. Medicine (Baltimore) 2016; 95, e5534.

11. Havlioglu N, Manepalli A, Galindo L, Sotelo-Avila C, Grosso L. Primary Ki-1 (anaplastic large cell) lymphoma of the brain and spinal cord. Am J Clin Pathol 1995; 103, 496-499.

12. Karikari IO, Thomas KK, Lagoo A, Cummings TJ, George TM. Primary cerebral ALK-1-positive anaplastic large cell lymphoma in a child. Case report and literature review. Pediatr Neurosurg 2007; 43, 516-521.

13. Kuntegowdenahalli LC, Jacob LA, Komaranchath AS, Amirtham U. A rare case of primary anaplastic large cell lymphoma of the central nervous system. J Cancer Res Ther 2015; 11, 943-945.

14. Menon MP, Nicolae A, Meeker H, Raffeld M, Xi L, Jegalian AG, Miller DC, Pittaluga S, Jaffe ES. Primary CNS T-cell Lymphomas: A Clinical, Morphologic, Immunophenotypic, and Molecular Analysis. Am J Surg Pathol 2015; 39, 1719-1729.

15. Nomura M, Narita Y, Miyakita Y, Ohno M, Fukushima S, Maruyama T, Muragaki Y, Shibui S. Clinical presentation of anaplastic large-cell lymphoma in the central nervous system. Mol Clin Oncol 2013; 1, 655-660.

16. Ozkaynak MF. Favorable outcome of primary CNS anaplastic large cell lymphoma in an immunocompetent patient. J Pediatr Hematol Oncol 2009; $31,128-130$

17. Park JS, Park H, Park S, Kim SJ, Seol HJ, Ko YH. Primary central nervous system ALK positive anaplastic large cell lymphoma with predominantly leptomeningeal involvement in an adult. Yonsei Med J 2013; 54, 791-796.

18. Ponzoni M, Terreni MR, Ciceri F, Ferreri AJ, Gerevini S, Anzalone N, Valle M, Pizzolito S, Arrigoni G. Primary brain CD30 + ALK1 + anaplastic large cell lymphoma ('ALKoma'): the first case with a combination of 'not common' variants. Ann Oncol 2002; 13, 1827-1832.

19. Rupani A, Modi C, Desai S, Rege J. Primary anaplastic large cell lymphoma of central nervous system-a case report. J Postgrad Med 2005; 51, 326327.

20. !!! INVALID CITATION !!!

21. Huang Y, Xie J, Ding Y, Zhou X. Extranodal Natural Killer/T-Cell Lymphoma in Children and Adolescents: A Report of 17 Cases in China. Am J Clin Pathol 2016; 145, 46-54.

22. Huang Y, Shi X, Zhong P, Wang Y, Xiao H, Zhou X, Yun J. De Novo Testicular Extranodal NK/T-Cell Lymphoma: A Clinicopathologic Study of 21 Cases With Review of Additional 18 Cases in the Literature. Am J Surg Pathol 2019; 43, 549-558. 
23. Brugières L, Deley MC, Pacquement H, Meguerian-Bedoyan Z, Terrier-Lacombe MJ, Robert A, Pondarré C, Leverger G, Devalck C, Rodary C, Delsol G, Hartmann O. CD30(+) anaplastic large-cell lymphoma in children: analysis of 82 patients enrolled in two consecutive studies of the French Society of Pediatric Oncology. Blood 1998; 92, 3591-3598.

24. Falini B, Pileri S, Zinzani PL, Carbone A, Zagonel V, Wolf-Peeters C, Verhoef G, Menestrina F, Todeschini G, Paulli M, Lazzarino M, Giardini R, Aiello A, Foss HD, Araujo I, Fizzotti M, Pelicci PG, Flenghi L, Martelli MF, Santucci A. ALK + lymphoma: clinico-pathological findings and outcome. Blood 1999; 93, 2697-2706.

25. Hapgood G, Savage KJ. The biology and management of systemic anaplastic large cell lymphoma. Blood 2015; 126, 17-25.

26. Stein H, Foss HD, Dürkop H, Marafioti T, Delsol G, Pulford K, Pileri S, Falini B. CD30(+) anaplastic large cell lymphoma: a review of its histopathologic, genetic, and clinical features. Blood 2000; 96, 3681-3695.

27. Williams D, Mori T, Reiter A, Woessman W, Rosolen A, Wrobel G, Zsiros J, Uyttebroeck A, Marky I, Le Deley MC, Brugières L. Central nervous system involvement in anaplastic large cell lymphoma in childhood: results from a multicentre European and Japanese study. Pediatr Blood Cancer 2013; 60, E118-121.

28. Ferreri AJ, Reni M, Pasini F, Calderoni A, Tirelli U, Pivnik A, Aondio GM, Ferrarese F, Gomez H, Ponzoni M, Borisch B, Berger F, Chassagne C, luzzolino P, Carbone A, Weis J, Pedrinis E, Motta T, Jouvet A, Barbui T, Cavalli F, Blay JY. A multicenter study of treatment of primary CNS lymphoma. Neurology $2002 ; 58,1513-1520$.

\section{Tables}

Table 1

Clinical Features of the Three Cases of Primary CNS ALK-positive ALCLs

\begin{tabular}{|c|c|c|c|c|c|c|c|c|c|c|c|c|}
\hline $\begin{array}{l}\text { Case } \\
\#\end{array}$ & $\begin{array}{l}\text { Age } \\
\text { (v) }\end{array}$ & Gender & $\begin{array}{l}\text { Initial } \\
\text { main } \\
\text { symptoms }\end{array}$ & $\begin{array}{l}\text { Clinical } \\
\text { History } \\
\text { (mo.) }\end{array}$ & $\begin{array}{l}\text { Initial } \\
\text { suspicion }\end{array}$ & Location & $\begin{array}{l}\text { Lesion } \\
\text { (s) }\end{array}$ & $\begin{array}{l}\text { Tumor } \\
\text { size } \\
\text { (cm) }\end{array}$ & $\begin{array}{l}\text { Surgical } \\
\text { excision }\end{array}$ & WBRT & $\begin{array}{l}\text { Chemotherapy } \\
\text { regimens }\end{array}$ & $\begin{array}{l}\text { Outcome } \\
\text { (mo) }\end{array}$ \\
\hline 1 & 16 & $\mathrm{M}$ & $\begin{array}{l}\text { Headache, } \\
\text { dizziness }\end{array}$ & 6 & Glioma & $\begin{array}{l}\text { Right } \\
\text { frontal } \\
\text { lobe }\end{array}$ & Single & $3.4 \times 2.7$ & Yes & No & Crizotinib & Alive, 18 \\
\hline 2 & 27 & $\mathrm{M}$ & $\begin{array}{l}\text { Headache, } \\
\text { vomiting }\end{array}$ & 2 & Tumor & $\begin{array}{l}\text { Right } \\
\text { parieto- } \\
\text { occipital } \\
\text { lobe }\end{array}$ & Single & $4.0 \times 3.0$ & Yes & Yes & $\begin{array}{l}\text { HD-MTX + Ara- } \\
\mathrm{c}\end{array}$ & Alive, 98 \\
\hline 3 & 12 & $M$ & $\begin{array}{l}\text { Headache, } \\
\text { vomiting }\end{array}$ & 4 & Infection & Cerebellum & Multiple & NA & Yes & Yes & $\begin{array}{l}\text { HD-MTX + VM- } \\
26+\text { HD-MTX } \\
+ \text { Ara-c }\end{array}$ & Alive, 52 \\
\hline
\end{tabular}

Table 2

Immunophenotype of the Three Cases of Primary CNS ALK + ALCL

\begin{tabular}{|c|c|c|c|c|c|c|c|c|c|c|c|c|c|c|c|}
\hline Case\# & CD30 & ALK & EMA & MUM1 & CD43 & $\mathrm{CD} 2$ & $\mathrm{CD} 3 \varepsilon$ & CD5 & CD7 & CD20 & PAX5 & TIA-1 & GranB & $\mathrm{Ki}-67$ & EBER \\
\hline 1 & + & + & + & + & + & Partial+ & - & - & Partial+ & - & - & + & + & $80 \%$ & - \\
\hline 2 & + & + & NA & + & + & NA & Partial+ & NA & NA & - & - & + & + & $60 \%$ & - \\
\hline 3 & + & + & + & + & NA & NA & - & NA & NA & - & - & + & + & $80 \%$ & - \\
\hline
\end{tabular}


Table 3

Clinical Features of the 20 Cases of Primary CNS ALK + ALCL Reported in the Literatures

\begin{tabular}{|c|c|c|c|c|c|c|c|c|}
\hline $\begin{array}{l}\text { Case } \\
\#\end{array}$ & Author & Age & Gender & Location & Lesion(s) & Treatment & $\begin{array}{l}\text { Follow up } \\
\text { (mo.) }\end{array}$ & Outcome \\
\hline L1 & Qian Liu et al.(4) & 12 & M & R. occipital to falx cerebrum & S & No & 1 & Died \\
\hline L2 & David H.George et al.(5) & 18 & $\mathrm{~F}$ & L. tempora, dura & S & $\mathrm{CT}+\mathrm{RT}$ & 62.4 & Alive \\
\hline L3 & Havlioglu et al.(11) & 4.5 & $\mathrm{~F}$ & $\begin{array}{l}\text { Brainstem, spinal cord, } \\
\text { meningeal }\end{array}$ & M & $\mathrm{CT}+\mathrm{RT}$ & 73.2 & Alive \\
\hline L4 & Buxton et al.(7) & 10 & $\mathrm{~F}$ & R. parietal, falx & S & $\mathrm{CT}+\mathrm{RT}$ & 6 & Died \\
\hline L5 & Abdulkar et al.(6) & 13 & M & R.parietal, frontal, meningeal & S & CT & / & Died \\
\hline L6 & Karikari et al.(12) & 4 & M & Frontal, parietal, pineal region & M & $\mathrm{CT}+\mathrm{RT}$ & / & Alive \\
\hline L7 & Merlin et al.(23) & 13 & M & Frontal, leptomeninges & $S$ & $\begin{array}{l}\mathrm{CT}+\mathrm{RT}+ \\
\mathrm{ABMT}\end{array}$ & 10 & Died \\
\hline L8 & Furuya $\mathrm{K}$ et al.(22) & 11 & M & Parietal, leptomeninges & M & $\mathrm{CT}+\mathrm{RT}$ & 98 & Alive \\
\hline L9 & Ponzoni et al.(18) & 29 & M & Frontal and temporal & M & $\mathrm{CT}+\mathrm{RT}$ & 19 & Alive \\
\hline L10 & P B Cooper et al.(9) & 39 & M & R.occipitoparietal & S & / & 9 & Alive \\
\hline L11 & Mark G Carmichael (8) & 38 & M & R. parieto-occipital & S & $\mathrm{CT}+\mathrm{RT}$ & 6 & Alive \\
\hline L12 & $\begin{array}{l}\text { Sindu Vivekanandan et al. } \\
(21)\end{array}$ & 20 & M & R. sylvian fissure & M & $\mathrm{CT}+\mathrm{RT}$ & 96 & Alive \\
\hline L13 & Masashi Nomura et al.(15) & 20 & M & L. frontal lobe & S & CT & 60 & Alive \\
\hline L14 & Jae Sung Park et al.(17) & 31 & M & Leptomenings & $\mathrm{S}$ & CT & 6 & Alive \\
\hline L15 & $\begin{array}{l}\text { Kuntegowdenahalli et al. } \\
\text { (13) }\end{array}$ & 18 & M & L. parieto-occipital & S & $\mathrm{CT}+\mathrm{RT}$ & / & / \\
\hline L16 & Splavski et al.(20) & 26 & M & Frontal horn & $S$ & $\mathrm{CT}+\mathrm{RT}$ & 24 & Alive \\
\hline L17 & Xiaoqin Dong et al.(10) & 34 & M & Spinal cord & M & $\mathrm{CT}+\mathrm{RT}$ & 25 & Died \\
\hline L18 & Madhu P Menon, et al.(14) & 43 & M & $\begin{array}{l}\text { Dural, leptomeningeal and } \\
\text { spinal }\end{array}$ & S & / & / & Died \\
\hline L19 & $\begin{array}{l}\text { Mehmet Fevzi Ozkaynak } \\
(16)\end{array}$ & 9 & M & $\begin{array}{l}\text { Bilateral frontal lesions, } \\
\text { meningeal }\end{array}$ & S & $\begin{array}{l}\mathrm{CT}+\mathrm{RT}+ \\
\mathrm{ASCT}\end{array}$ & 26 & Alive \\
\hline L20 & A Rupani et al.(19) & 17 & M & R. fronto-parietal & M & $\mathrm{CT}+\mathrm{RT}$ & 1 & Died \\
\hline
\end{tabular}

M, male; F, female; mo., months; /, not available; R., right; L., left; CT, chemotherapy; RT, radiotherapy; ABMT, allogeneic bone marrow transplantation; ASCT, autologous peripheral blood hematopoietic stem cell transplantation. 
Table 4

Summary of the Brief Clinicopathologic Features of Primary CNS ALK + ALCL in Present Study and the Literature

\begin{tabular}{|llll|}
\hline Characteristics & Present study & Literature & Total \\
\hline Total cases & 3 & 20 & 23 \\
\hline Age Range & $12-27$ & $4-43$ & $4-43$ \\
\hline Median Age (year) & 16 & 18 & 18 \\
\hline Male/female & $3: 0$ & $17: 3$ & $20: 3$ \\
\hline Location & & & \\
\hline Brain & 3 & 12 & 15 \\
\hline Leptomenings & 0 & 1 & 1 \\
\hline Spinal cord & 0 & 1 & 1 \\
\hline Brain, leptomenings and (or) spinal cord & 0 & 6 & 6 \\
\hline Solitary lesion/ multiple lesions & $2 / 1$ & $11 / 9$ & $13 / 10$ \\
\hline Follow up Rang (months) & $18-98$ & $1-98$ & $1-98$ \\
\hline Median follow-up (months) & $52(\mathrm{n}=3)$ & $21.5(\mathrm{n}=16)$ & $24(\mathrm{n}=19)$ \\
\hline Outcome (died/alive) & $0 / 3$ & $7 / 12$ & $7 / 15$ \\
\hline 2-years overall survival & $100 \%$ & $62 \%$ & $69 \%$ \\
\hline
\end{tabular}

Table 5

Primary Antibodies and Conditions Used for Immunohistochemical Staining

\begin{tabular}{|lllll|}
\hline Antigen & Clone & Dilution & Antigen Retrieval & Manufacturer \\
\hline CD20 & L26 & $1: 200$ & EDTA, pH9.0 & Ascend BIO, China \\
\hline CD19 & BT51E & $1: 200$ & EDTA, pH9.0 & ZSGB BIO, China \\
\hline PAX5 & ZP007 & $1: 50$ & EDTA, pH9.0 & Ascend BIO, China \\
\hline CD3 & 2 GV6 & RTU & EDTA, pH9.0 & Roche, China \\
\hline CD5 & 4C7 & $1: 100$ & EDTA, pH9.0 & Ascend BIO, China \\
\hline CD2 & AB75 & $1: 30$ & EDTA, pH9.0 & Gene, China \\
\hline CD7 & EP132 & $1: 100$ & EDTA, pH9.0 & Gene, China \\
\hline CD4 & UMAB64 & $1: 100$ & EDTA, pH9.0 & ZSGB BIO, China \\
\hline CD8 & SP16 & $1: 75$ & EDTA, pH9.0 & Gene, China \\
\hline MUM1 & EP190 & RTU & EDTA, pH9.0 & ZSGB BIO, China \\
\hline CD56 & 123C3 & $1: 600$ & EDTA, pH9.0 & ZSGB BIO, China \\
\hline TIA-1 & 2G910F5 & $1: 75$ & EDTA, pH9.0 & Gene, China \\
\hline Granzyme B & GZB01 & $1: 75$ & EDTA, pH9.0 & Gene, China \\
\hline Perforin & 5B10 & $1: 50$ & EDTA, pH9.0 & Gene, China \\
\hline ALK & ALK1 & $1: 200$ & EDTA, pH9.0 & Ascend BIO, China \\
\hline CD30 & JCM182 & $1: 100$ & EDTA, pH9.0 & Gene, China \\
\hline Ki-67 & MIB-1 & RTU & EDTA, pH9.0 & Dako, Denmark \\
\hline RTU: Ready to use. & & & \\
\hline
\end{tabular}



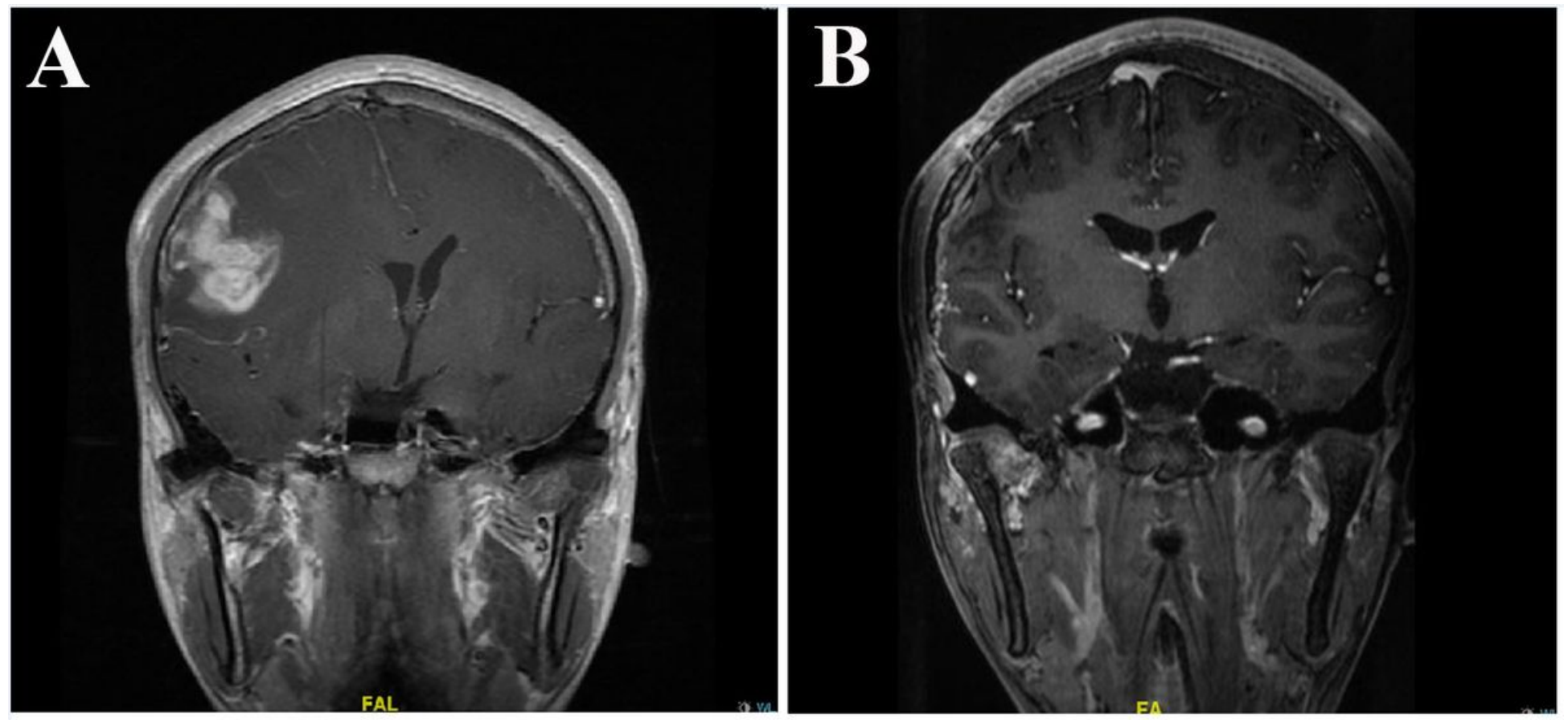

Figure 1

Pretherapeutic and post-therapeutic magnetic resonance imaging (MRI) scans of the mass in right frontal lobe for Case\#1.

Pretherapeutic MRI examination showed a mass in right frontal lobe with large area cerebral edema (A). MRI undertaken after surgical excision and Crizotinib treatment revealed no residual enhancement, which suggested complete remission (B). 

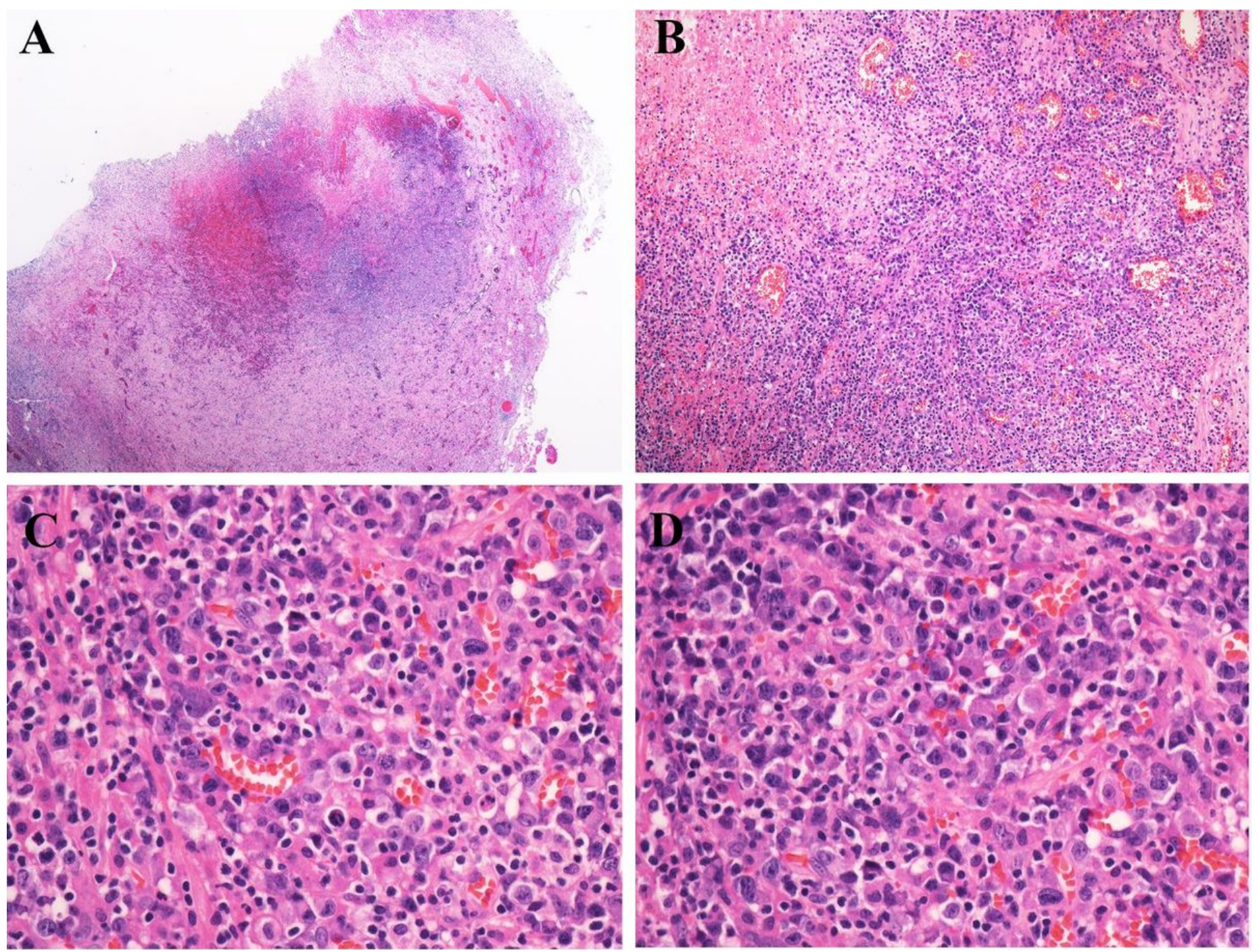

\section{Figure 2}

\section{Morphology of primary CNS ALK+ ALCL}

Normal brain architecture was replaced by lymphoid cells (A). The tumors had a diffuse growth pattern, and some neoplastic cells often clustered around blood vessels (B). The lymphoma cells were of medium to large size with abundant cytoplasm and irregular nuclei. The nuclear chromatin was finely clumped or dispersed, with prominent nucleoli (C-D). 


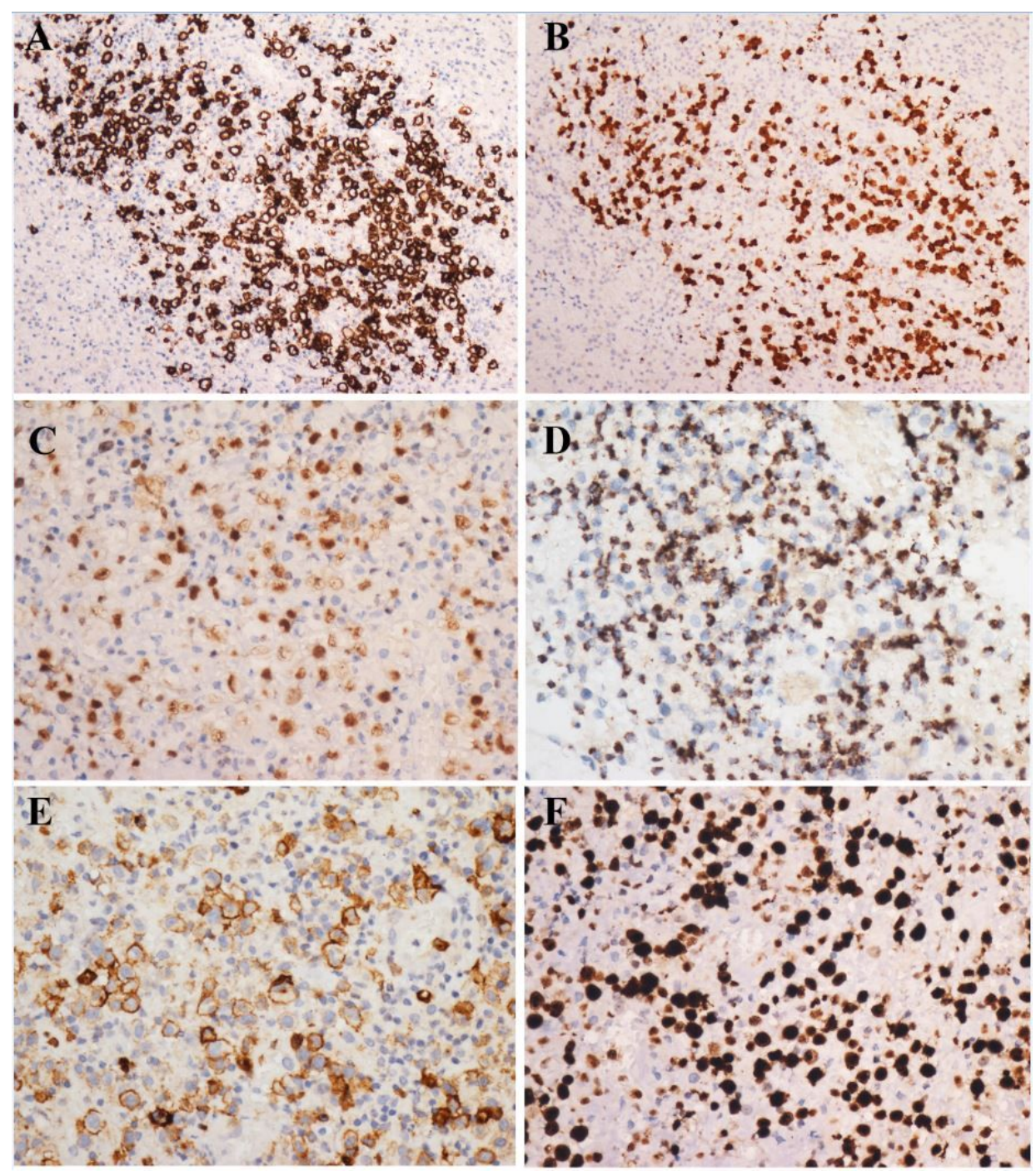

Figure 3

Immunophenotype of primary CNS ALK+ ALCL

The neoplastic cells were strongly positive for CD30 on the cell membrane and in the Golgi region(A). ALK-1positivity was identified with staining in both cytoplasm and nucleus (B). The tumor was positive for MUM1(C) and TIA1(D). Two available cases were positive for EMA (E) and Ki-67 (F).
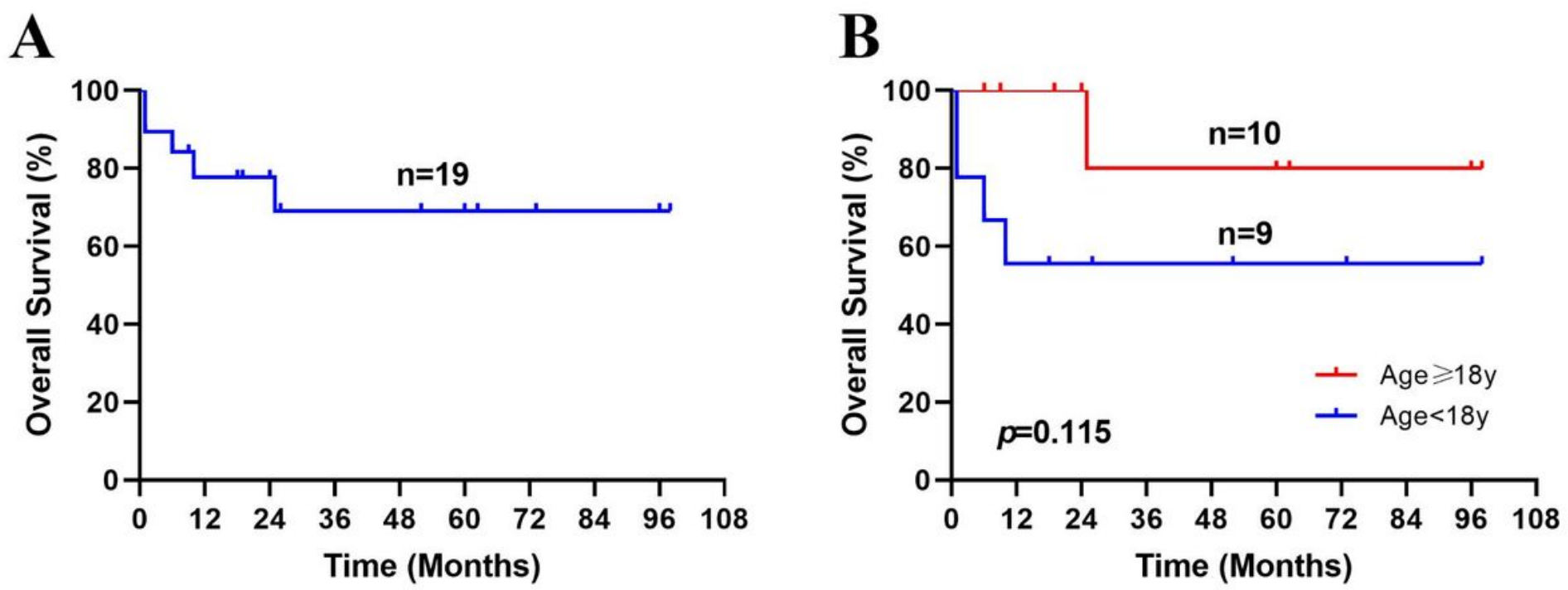

Figure 4 
Overall survival (OS) analysis for primary CNS ALK+ ALCL

The2-year overall survival (OS) of patients with primary CNS ALK+ ALCL was 69\% (A). Patients under 18-years old had worse 2-year overall survival, but the difference did not reach statistical significance $(p=0.115)(\mathrm{B})$. 